\title{
River Notes: A Natural and Human History of the Colorado
}

\author{
Wade Davis. 2012 Island Press. Pp. $176 \$ 23.63$ (Hardcover). ISBN 978-1610913614 \\ Reviewed by Thomas W. La Point \\ Reviewer address: Department of Biological Sciences, University of North Texas, 1155 Union Circle \#305220, Denton, TX \\ 76203. lapoint@unt.edu
}

Received: September 20, 2013

Volume: 4:110-112

Published: November 4, 2013

(C) 2013 Society of Ethnobiology

This is a wonderful book on the cultural and natural history of the Colorado River and the demands on the water it carries. The book presents a geological, cultural and biological panorama of Colorado River water throughout history, beginning with the formation of the Colorado River drainage, and then neatly describing the relation between water and human culture. The book focuses largely on the lower portion of the river, and delights in its descriptions of canyons, Anasazi, Hopi and Zuni culture, water demands, and recreation in present and past. The book carries a serious warning about how we are presently using Colorado River water (abusing, actually) and what the root cause is of this disturbing waste of a precious resource.

\section{Historical Use of the River}

Davis' background as a highly regarded ethnographer comes into play early as he describes the early essay by Aldo Leopold, in which Leopold canoes down lower Colorado River through the delta formed as the river flows into the Gulf of California.

In the book, Davis weaves together a great section about the use of water by the ancients, the Anasazi and more recently the Hopi and Zuni. The Anasazi had elaborate dams and water control structures and recognized the value of water. It was ingrained into their culture. As water became scarce, the society fell apart and the people drifted into smaller groups, away from the areas surrounding the present-day "four corners" area of the US. He writes about the Hopi of the First Mesa. Their water problems are legion, not to mention the daily difficulties of keeping youngsters in the area, continuing to be part of the culture. In each case, their beliefs of origin reflect "their astonishment as they took in the canyon's beauty, the painted rocks and magical animals, the springs and lush plantings by the shallows of Bright Angel Creek, the fulcrum of creation on the canyon's rim where they first saw sunlight crack open the sky" (Page 37).

\begin{abstract}
Mormon Use of the River
In the book, Davis describes the early (1800's) Mormon colonizers and evangelists, like Jacob Hamblin and John Lee (for whom Lee's Ferry, the definitive start of float trips through the Grand Canyon, is named). To quote, "their mission, inspired by God, was to settle and make fertile the desert wastes" (Page 34). This brought to mind a recent course field trip I took with students from the University of North Texas. The course concerns agricultural, recreational and municipal water use in the west, focused largely on the Colorado and Green River basins. We had visited the promontory in Canyonlands, from which one could see the confluence of the Green and Colorado rivers. As we were returning from the short hike to the viewpoint, we met a Mormon scout leader with his troop of scouts. $\mathrm{He}$ was telling them that "all that open land (just upstream from Cataract Canyon!) was a waste and should be built on!" I was astounded by his remark and remain ashamed to this day that I did not call him out to ask about his feelings of wilderness and the value of open land. He obviously continues the divinely-inspired vision of all lands being filled with humans. No different than in the 1870's.
\end{abstract}

\section{Running the Colorado}

The excitement one feels as one readies rafts or dories for a Grand Canyon trip cannot be adequately described in words, even in this book. I have floated this stretch five times during my life and each trip was a total immersion (pun intended) in a part of the globe that is most profound, beautiful, awe-inspiring, and at times harrowing. Davis describes his trip down the Colorado through the Grand Canyon with a professional group, and brightly describes the excitement he felt has he traversed the roaring 20 's, 
Badger Creek, Hance, Granite, Crystal, the jewels, and Lava. Davis' book does a great job of intertwining the views and experiences on his trip with those of John Wesley Powell, the first director of the US Geological Service and the key voice warning against agrarian development of the western states. He cautioned against such development, as water was too limiting. Powell's ideas, of course, were swept aside by developers, politicians and land agents intent on selling land, dreams, and abundance.

Davis was on a commercial trip and notes that private trips do give one more time to take side hikes up remote canyons. Hikes into side canyons lead to sublime views and an absolute quiet that exists nowhere else that I know. On one private trip, we hiked up Matkatamiba Canyon. The clear water of the creek poured in a little rivulet down the base of this amazing canyon, with overhangs covered with seeps, ferns and mosses. Around the trail is a riot of flowers, including camas lilies, datura, figworts, asters, and penstemons. All this, however, pales in comparison to the stillness of the canyon (excepting the wonderful cadence of a canyon wren). Stillness that no one in a city can anymore imagine; stillness that allows the blood coursing through one's temples to sound loud. Such stillness has "to be not heard" to be believed. I personally think that John Muir's (1938 cited in Dunlap 2009) statement "In God's wildness lies the hope of the world - the great fresh, unblighted, unredeemed wilderness" is really a reference to the quiet and peacefulness in such places.

In my own trips and on Davis' trip down the river, an amazing variety of boats and technical equipment are now employed that help folk to get safely downstream: multi-compartment rafts, wide dories, life preservers capable of holding $24 \mathrm{lbs}$ of deadweight up in the water, and coolers capable of holding ice for $10-12$ days. Compared to what Powell had, it is a life of luxury. Yet, it still is true that the river itself decides which boat to let through its rapids - and determines which side ends up upright. I had been feeling fairly smug on my fifth trip, as on the previous four I had not flipped in any Colorado River rapids. On my fifth trip, we flipped in Houserock, an 8 on the scale of 10 used to describe the difficulty of the rapids. In House Rock I was too far left and the curling wave off of the house-rock sized boulder on lower left curled my little 16 foot boat over - and humbled me greatly. After that, I was much more careful in placing the boat in the current. Davis writes about running Lava, one of the great rapids of North America: " there are two types of people, those who have flipped and those that will." To that, I add one more truism (from Dick Barker, co -owner of Barker-Ewing Raft trips in Jackson Hole WY): "There are old boatmen, and there are bold boatmen. However, there are no old, bold boatmen." The river decides and requires respect.

I had to chuckle to myself how Davis describes his raft trip down the Canyon, with Lava falls as the climax of the trip. I have experienced on every trip the same attitude among fellow participants: Lava Falls is so huge, overwhelming, and just plain scary, and had been anticipated for so long, that running it effectively ends the raft trip. In truth, there are usually two or three full days after Lava to enjoy the canyon, wonderful vistas, and several more great rapids. However, on every trip we have taken, the "trip is over" at Lava. Folks begin talking about the shuttle to Flagstaff, via Kingman, getting a real shower, etc. All I have thought of is "how do I get on the river again?"

\section{Loss of Glen Canyon}

I have read much of the loss of Glen Canyon. Many books, including this one, have written about how beautiful the canyon was and how many ancient ruins were lost by raising the level of Lake Powell. I am sure John Wesley Powell turned in his grave when the great river he explored was dammed behind Glen Canyon dam - and then named for him in an ultimate irony. Perhaps it should have been named "Lake Dominy" for the Bureau of Reclamation Water Master who saw any water passing a given location as "wasted water." Davis eloquently writes of guides on Lake Powell describing the "islands" around which they boat, forgetting that each island is a "drowned butte." Thinking three-dimensionally is a good way to visualize what was lost under the waters.

The link between Powell and the Colorado River - and his exploration of this part of the west - cannot be overstated. Davis writes extensively of this, summarizing Powell's explorations of the Green River (the major tributary to the Colorado, joining it upstream from Cataract Canyon) and then down into the unknown terrors of the canyon's immense rapids. Powell's determination to travel down the canyon is epic; he and his team faced difficulties unimaginable now to river runners. Historically, however, the most visionary aspect of Powell was his warning to Congress about inhabiting this desert country. It was not suited at all for the typical farm, he warned. He actually suggested that state borders be based on 
watershed boundaries. Sadly, his warning suggestion was ignored for political and economic expedience.

The dam itself has always been controversial because of the phenomenal canyon it flooded. One commercial or cultural aspect of the dam is the electrical power it produces. A tour of the dam provides insight into the tremendous power of the stored water behind it. Seven wires, albeit large ones, leave from Glen Canyon Dam. They carry 1.3 million kilowatts of power produced by eight generators in the dam, each powered by water from the hypolimnion of Lake Powell. That power provides electricity for cities, commerce and recreation in several western states. The cold hypolimnetic release, cold and clear, allows trout to be caught downstream as far as Lee's Ferry. This is totally unnatural and has disrupted the ecology of the endangered fish in the Colorado River downstream from the dam.

As Davis writes, the dam provides power not only for municipalities, but also for agriculture - there is an electrical cost for transporting water for agriculture. The more than 60,000 water systems and 15,000 wastewater systems in the United States are among the country's largest energy consumers, using about 75 billion $\mathrm{kWh} / \mathrm{yr}$ nationally-3 percent of annual U.S. electricity consumption (NRDC 2010). I am sure that most people do not recognize the "water cost" of food on their table, nor do they recognize the ecological cost of running water through a tap or faucet. It takes either burning coal (as in Texas) or turning a turbine to produce enough electrical power to pump water through the various treatment plants, through delivery pipes, up to municipal water storage towers, then into each home or business. The cost is real, in terms of what we expect from the Colorado: In southern California, pumping one acre-foot of Colorado River Aqueduct water to Southern California requires about $2,000 \mathrm{kWh}$. According to an estimate from the Metropolitan Water District of Southern California, the amount of electricity used to deliver water to residential customers in Southern California is equal to one-third of the total average household electric use in Southern California. It also provides the power for lifting water over mountains into agricultural irrigation systems.

\section{On Our Being Homo sapiens}

The final chapter of Davis' great book ends on a cautionary note for all. Water is not recognized for the valuable resource it is. Agricultural water demands on the Colorado River largely go for cultivating alfalfa, a feed used primarily for cattle. Alfalfa is a water-hungry forage and depends on overhead sprinkling systems. Such systems lose as much as $50 \%$ of the water applied during hot summers. The U.S. subsidies for irrigating range land in the west, with Colorado River water, are huge. Davis writes that the cost to farmers is $\$ 17$ per acre foot, whereas municipal costs are closer to $\$ 1500$ per acre-foot. In that arid climate, using precious Colorado River water to grow alfalfa to feed cattle, brings home an important point: society should be able to change this horribly wasteful practice. I think it should, as does Davis. It becomes a personal choice, as consumers (or, as I like to think of it, as educated humans) decide whether or not to continue to eat as much beef as we do. It also becomes increasingly important to participate in civics, as voters. We can and should vote down such subsidies. As he elegantly describes it, "..even assuming that all such wanton habits of consumption can be dramatically curbed, no conservation initiative can succeed that gives a free pass to the cattle industry."

As humans, we should be able to contemplate the consequences of our actions; hence, the term "Homo sapiens." However, we seem to be disregarding efforts to control our affluence, our greed and our demand for ever more resources to be used ever more quickly. Rather than following the advice of Gifford Pinchot, who said, "the best use for the most people for the longest time," we are taking the first two thirds of that advice, at our risk. The mantra has become: "the best use for the most people now, not later." We cannot go on in this and Davis points this out in his last chapter, in which he lays out the problem: we are growing a water-hungry plant alfalfa in dry country to feed cattle for our consumption. Public education is a must here, as many folk have not made the connection. They cannot see their way to "connect the dots.

Davis ends his book by suggesting we re-visit the delta where the Colorado River enters the Gulf of California. His description evinces the growth that could occur and the riot of life that would ensue if water were to once again flow into the Gulf. I am convinced that, if we do not hear this warning, we will perish in the desert.

\section{References Cited}

Muir, J. 1938. John of the Mountain: The Unpublished Journals of John Muir. Cited in Dunlap, D. 2009. The National Parks: America's Best Idea, pp. 43. Alfred A. Knopf Publishers, Toronto. 